\title{
IMPLEMENTATION OF ACTIVE LEARNING TWO STAY TWO STRAY COOPERATIVE MODEL IN SOCIAL STUDIES
}

\author{
Seno Budhi Ajar ${ }^{1}$, Nur Dawam ${ }^{2}$ \\ ${ }^{1}$ Geography Education, Faculty of Teacher Training and Education, \\ Universitas Sebelas Maret \\ ${ }^{2}$ Junior High School 9 Surakarta \\ Email: senobudhiajar@gmail.com
}

\begin{abstract}
In the 2013 curriculum, learning is focused on student centers or known as active learning. This study aims to determine the obstacles faced in implementing active learning two stay two stray cooperative model and their effects on social studies outcomes of junior high school students. This research is a classroom action research with research subjects in the form of 8th grade students of Surakarta 9th Junior High School, Surakarta City, Central Java Province. The research method used in data collection is a participant observation method in which the researcher acts as a teacher to find out the obstacles when implementing active learning two stay two stray models and the test method is used to measure the ability of student learning outcomes. The data analysis technique used is comparative descriptive analysis and critical analysis. The results of this study are (1) there are four aspects that become obstacles when applying active learning two stay two stray cooperative model in social studies subjects namely aspects of time management, classroom management, learning resources, and student activity. (2) active learning two stay two stray cooperative model very effective in improving student learning outcomes.
\end{abstract}

Keywords: Two Stay Two Stray Cooperative Model; Learning Outcomes; Constraints

\section{A. INTRODUCTION}

The current Indonesian curriculum is a curriculum that prioritizes Student Centers so passive learning is less relevant in this curriculum. passive learning passive where students only receive information and ideas from the teacher's explanation (Fink, 2003), it should not be used again by the teacher when learning. the small amount of activity from passive learning makes students feel bored quickly. In such conditions students are often lazy to listen to the teacher's explanation and answer questions from the teacher. this can be seen from students who often put their heads on the table or even their own stories with other friends. this might be the reason why student learning outcomes especially social studies have not been optimal. In overcoming this problem, the teacher must choose an active learning model - learning where students can do and observe learning independently or in groups and be able to reflect on what and how in learning (Fink, 2003). 
To improve the quality of the learning process and learning outcomes, teachers should try the Active Learning method because it is more interactive than the passive learning method. One of the active learning models is the Cooperative Model. According to (Lie, 2007), the cooperative learning model is a teaching system that gives students the opportunity to work together with other students in completing structured tasks.

Cooperative learning model has many types, one type is Two stay Two Stray Cooperative Model. According (Darmawan \& Sujoko, 2013) Two StayTwo Stray cooperative model is a learning model with a group system where there is a division of roles in it. In this method the roles in groups are divided into two. the first is the role of the host in charge of delivering the results of the discussion to other groups. The second is the role of guest who is in charge of receiving the results of other group discussions. With this role in the group, the Two Stay Two Stray learning model aims to make students work together, be responsible, help each other solve problems, and encourage each other. Langkah kooperatif Two Stay Two Stray, According to the (Lie, 2007) in her book Cooperative Learning is: (1) Students work together in groups of four as usual. (2) When finished, two students from each group will leave the group and each visit to another group. (3) Two students who live in groups are tasked with sharing their work and information with their guests. (4) Guests excuse themselves and return to their own groups and report their findings from other groups. (5) Groups match and discuss the results of their work.

The Two Stay Two Stray Cooperative Model can be able to involve students in the whole learning process and can involve all aspects, both cognitive, affective and psychomotor aspects of students. By implementing Two Stay Two Stray learning, it is expected to improve student learning outcomes in social studies lessons. Based on this background, the authors are interested in studying more about the implementation of the Two Stay Two Stray learning approach in social studies learning through research with the title "Application Of Active Learning Two Stay Two Stray Cooperative Model In Social Studies (Case Study In Surakarta 9th Junior High School)".

The reason for using the Two Stay Two Stray cooperative learning model or two staying two guests was developed by Spencer Kagan in (Huda, 2014) because this technique can be developed with Numbered Head techniques and this technique can also be applied to all 
subjects and levels age. The use of the two stay two stray technique allows each group to share information with other groups.

The purpose of this study is to improve social studies learning outcomes and obstacles when applying the type two stay two stray correlative learning method. The hypothesis of this study is the use of two stay two stray cooperative learning methods can improve student learning outcomes, even though there are minor obstacles.

\section{B. MATERIALS AND METHODS}

This research will be conducted at the Surakarta 9th Junior High School, which is located at Jalan Sekar Jagad, Pajang Village, Laweyan District, Surakarta City, Central Java Province. This research was conducted in odd semester, 2019/2020 school year. The class studied was grade 8 . This research was conducted for 5 months, from July to November 2019. Data collection techniques used are:

\section{Participant Observation Methods}

This method is used to collect the obstacles encountered when applying active learning Two Stay Two Stray cooperative models researchers served as implementing teachers in learning activities. The researcher conducts learning by combining the principles of active learning with the Two Stay Two Stray cooperative models.

According to (Fink, 2003) active learning starts from finding information and ideas, doing and observing, and reflecting.

- The first step is to find for information and ideas in this step the researcher provides several articles with different themes in each group. Students find for information and ideas not only from textbooks but also from articles that are shared.

- The second step is the experience of doing. The experience of doing here is making scientific posters. each group writes down the information and ideas that they get from textbooks and articles into a cardboard measuring A3 $(29.7 \mathrm{~cm}$ $\mathrm{x} 42 \mathrm{~cm}$ ).

- The third step is observing experience. This step uses the principles and methods of the Two Stay Two Stray cooperative model.

- The fourth / final step is reflection where group representatives are asked to reflect on current learning.

The steps the researcher applied follow the steps of active learning in the Tanoto Foundation's "PINTAR" program. 


\section{Test method}

This method is used to measure student learning outcomes. The test conducted is a test made by the teacher without the intervention of researchers. Both pre and post learning.

The test is carried out twice in a multiple choice form (pre test and post test). The pre test is carried out before starting the lesson and the post test is carried out after the lesson

The test used is the cognitive domain of the bloom taxonomy domain which uses C2 (understanding reports, tables, diagrams, directions, regulations, etc.) and C6 (assessment of solutions, ideas, methodology) (Hamdani, 2009).

\section{RESULTS AND DISCUSSION}

\section{Characteristics of Students and} Research Locations

Surakarta City is one of the cities in the central part of Java. Facilities and infrastructure of the City of Surakarta are very adequate including the education sector. One of the educational facilities is Surakarta 9th Junior High School which is one of the best junior high school in Surakarta. Physical facilities owned by Surakarta 9th Junior High School are fairly good, in the classroom facilities that researchers use there are LCD projectors, whiteboards and boardmakers, fans, and each child is lent one textbook in each lesson by the school. The condition of students of Surakarta 9th Junior High School is good not only in cognitive but also in mastering technology.

Obstacles in the Application of Active Learning with the Two Stay Two Stray Cooperative Model

The obstacles faced when implementing active learning with the cooperative model of Two Stay Two Stray techniques in Surakarta 9th Junior High School, there are 4 aspects namely Time, class management, learning resources and student activity.

1. Time Management

The time for one meeting in social studies for junior high school is $2 \times 45$ minutes. This is reduced by 10 minutes for apperception and closing, so the time spent on applying active learning is 70 minutes.

There are 3 aspects of time management namely setting priorities, time management mechanisms, and timing of time (Tiger, 1994). In learning activities there are 3 activities, namely preliminary activities, core activities, 
and closing activities. At the core activities there are 4 steps of active learning. The main priority is the core activities, especially the third and fourth steps. The time management mechanism stated in the Learning Implementation Plan Document is used to allocate 5 minutes of opening activities, 15 minutes for the first step, 25 minutes for the second step, 20 minutes for the third step and 10 minutes for the fourth step, and 5 minutes of closing activities. The problem is the control of time. in the second step, namely the step of experience to do by making works. The second step takes 30-40 minutes. There are two reasons students need more time in the second step, namely:

- Students still often read and fixated on teaching materials both in the form of articles and textbooks when pouring ideas and information into their work.

- Ideas and information poured into A3-sized paperboard $(29.7 \mathrm{~cm} \mathrm{x} 42 \mathrm{~cm})$, not only pay attention to the contents of the ideas and information but also decorate the carton.

Likewise in the third step, the step of applying the two stay two stray model process also requires a longer time than planned in the Implementation Plan Document of around 25-30 minutes. therefore in time management need to pay attention to the effectiveness and efficiency in the second and third steps. The students take the second and third steps need to be considered, both of these steps there is a lack of focus in discussing the contents of the material. This student's lack of focus makes the time needed longer than the planned time.

\section{Class Management}

Active learning makes the classroom more alive than passive learning. The opposite of calm conditions in passive learning, in active learning classroom conditions can be rowdy. If classified into class types according to (Harsanto, 2007), classes in active learning belong to the type of rowdy class but the atmosphere is more positive. this happens because the process of discussion and making works that are part of the second step, make sounds louder than passive learning. Likewise in the third step of the activity of moving places, explaining and asking questions can also make a louder voice. the condition of the chairs and tables is also a bit messy 
because of the processthe teacher must be more active in classroom management especially in the second and third steps than in passive learning.

\section{Learning Resources}

There are four main components of learning resources, namely messages, people, tools, and routine procedure techniques or references (Hafid, 2011). there are two components of learning resource obstacles on active learning, namely messages and tools.

- Messages

The rules of the Surakarta 9th Junior High School not only forbid students to carry cell phones, but also the use of textbooks sourced only from 1 textbook on each lesson lent by the school. This causes students to only focus on the source of one textbook, thus affecting learning activities. Although students have been given several articles, students are still more dominant using textbooks than using articles in making work. It is because social studies textbooks are easier to understand than the articles. Students have a little difficulty in extracting the essence of the article and the allocation of time in the first step is less if they have to understand 3-4 articles, so the message in student work is dominated by references from textbooks.

The dominance of the use of social knowledge textbooks influences the work produced in the second step. Although the students' work has a good development of content and message in their work, it has similar patterns and structures in the textbooks.

- Tools

The tools for active learning activities type two stay two stray cooperative models are more than the passive learning lecture method. Besides that, active learning in the two stay two stray cooperative model also uses more consumable tools while passive learning methods lectures using non-consumable tools. If the passive learning method of lectures uses textbooks, laptops, power point slides and LCD projectors to deliver messages, while active learning the two stay two stray cooperative model not only uses tools such as the passive learning method of lectures but also uses other tools such as printed articles, markers color, A3 cardboard / paper from used calendars and colored paper in 
which the number of tools is adjusted to the number of groups made.

\section{Student Activity}

Learning activities are classified into 8 groups namely Visual Activities, oral Activities, Listening Activities, Writing Activities, Drawing Activities, Motor Activities, Mental Activities, and Emotional Activities (Diedrich dalam Sardiman, 2012). Active learning of the two stay two stray type cooperative model already contains all eight activities. The problem is the division of tasks in groups. students who are good at oral activities will always want to provide explanations in the third step instead students who are not proficient in oral activities tend to avoid them. Likewise in the second step when making a work, students who are good at drawing activities are always tasked with decorating the work to make it look interesting and students have the advantage in writing activities will be assigned to make the contents of the material in the work.

The problem is that if the researcher gives students the freedom to manage independently in the second and third steps, all students will carry out activities that they only like. Conversely, if researchers arrange the assignment of each student in the second and third steps, the time needed will be longer and interfere with time management.

The Impact of Active Learning Two Stay Two Stray Cooperative Model Against Student Learning Outcomes

1. Score Comparison of Pre-post Active Learning Outcomes

Surakarta 9th Junior High School is one of the best junior high schools in the city of Surakarta so the Minimum Criteria for Completion is quite high. Students are declared complete in learning if the student gets a score of $\geq 75$ because the standard score for the minimum completeness criteria is 75 .

Based on active pre-learning learning outcomes of the two stay two stray cooperative model it is known that the average score of students is 69.06. The average score is below the minimum completeness criteria score of 75 . 


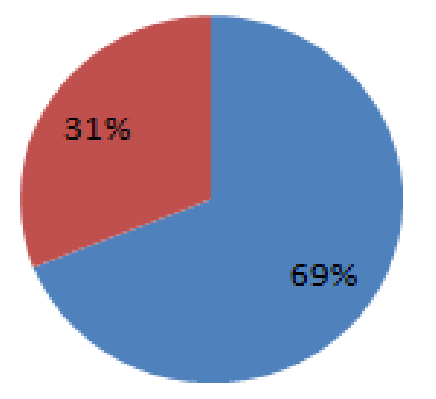

Figure 1. Percentage score passed pre-active learning.

The number of students having a passing score is quite low from 32 students, only $31 \%$ of students have a grade of $\geq 75$ and the number of students who have not yet passed more than half the number of students. $69 \%$ of students have a score of less than 75 . Pada $69 \%$ siswa yang dinyatakan tidak tuntas $52 \%$ diantaranya berada pada rentangan nilai 60-74, sedangkan In $69 \%$ of students who have not yet passed the score, $52 \%$ of them are in the $60-74$ range and $17 \%$ of students have a poor score below $60.31 \%$ of students who have graduated scores, $28 \%$ are in the $75-85$ range, while $3 \%$ have excellent scores of $\geq 85$.

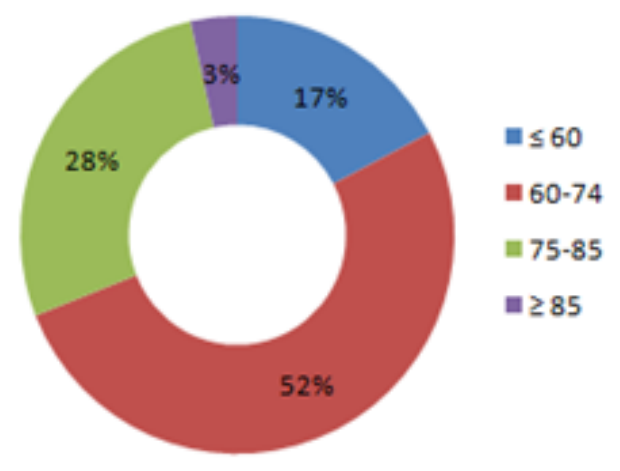

Figure 2. Percentage score students pre-active learning.

After active learning the two stay two stray cooperative model produces positive values on student learning outcomes. the average score in the class increased by 11.84 points to 80.9 above the Minimum Completion Criteria Score. 


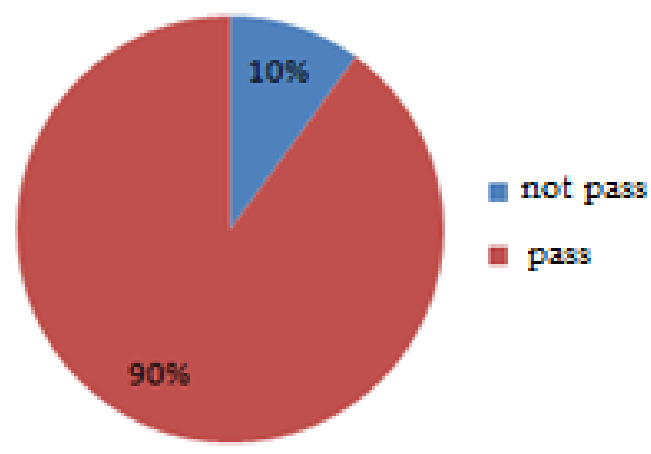

Figure 3. Percentage score passed post-active learning

Learning after active learning can be said to be successful because of 32 students, $90 \%$ of them already have a score above the Minimum Mastery Criteria score. That means almost all students have passed. Only $10 \%$ of students have not reached the minimum passing score. $90 \%$ of students who score above the Minimum Mastery Criteria score, as many as $69 \%$ of students' scores are in the range of $75-85$, even more than one fifth of students or $21 \%$ of students have a score of $\geq 85$. while $10 \%$ of students who score below the minimum completeness criteria score. $7 \%$ of students have scores that are in the 60-74 score range and only $3 \%$ have students who score less than 60 .

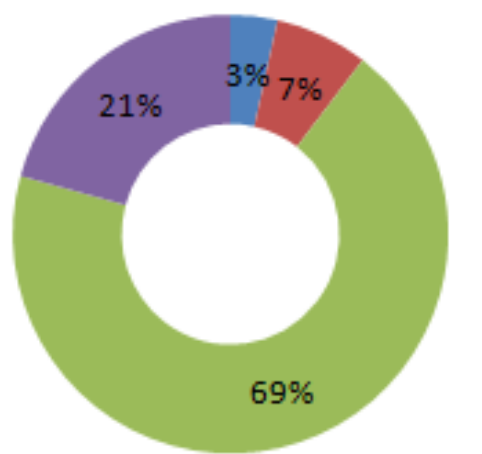

Figure 4. Percentage score students post-active learning. 


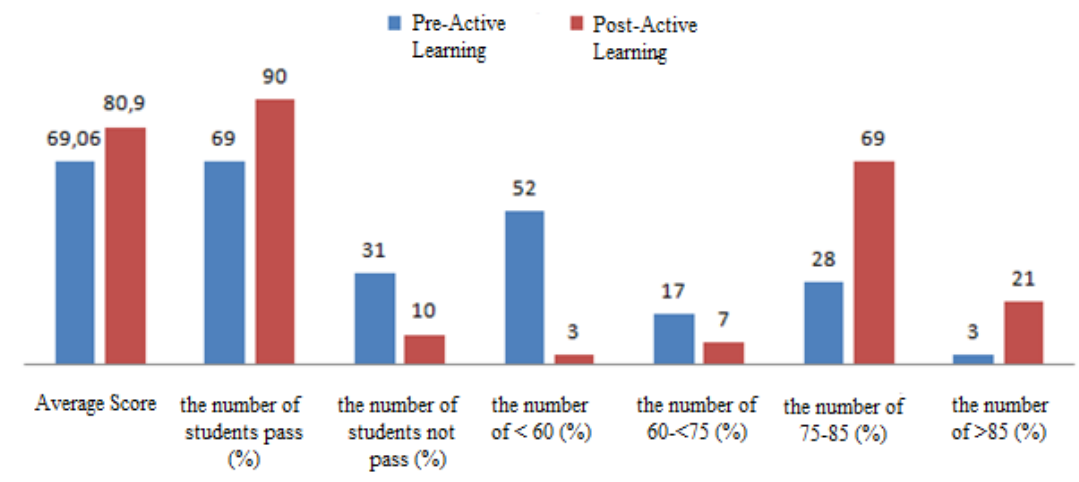

Figure 5. Histogram of Student Learning Outcomes in the Conditions of Pre Test and Post Test Active Learning

Based on the data above shows that the active learning two stay two stray cooperative model has been successful. This is caused by the activities and learning outcomes of students of research subjects having a score above reaching the Minimum Completion Criteria set by the school with an average score of 80.9 and achieving targets reaching $90 \%$ of the total number of students of the research subjects.

(Koç et al., 2013) say that a cooperative learning method affect in a positive way the students' academic achievements. Likewise in this study, the active learning of the Two Stay Two Stray cooperative model can improve student learning outcomes in social studies.

2. The Effect of Cooperative Learning on Students
Cooperative learning has a positive effect on students. First, when student do activities, students in doing group work- help each other. one can assume that seeing their own improvement level and making more contributions to their group with the effort they spent motivated the students who had low academic achievement in the beginning (Ari \& Sadi, 2019). Second, students work together to complete the assigned task so that students' social abilities are formed. Likewise (Alrayah, 2018) says cooperative learning make students learning valuable social skills (resolving conflict, problem solving, criticizing ideas and not people, paraphrasing, asking questions, giving direction to the group's work, and building on each other's information). 


\section{CONCLUSIONS}

Based on a theoretical study, research results, and discussion, conclusions can be drawn that (1) the obstacles faced when applying active learning in the two stay two stray cooperative model is in the minor but related categories. Time management, classroom management, learning resources and student activity. (2) The implementation of active learning in the type two stay two stray cooperative method can improve the learning outcomes of Social Knowledge students both passing learning outcomes and increasing learning outcomes scores.

This study only examines the cognitive domain, future research will be carried out to test the effectiveness of the two stay two stray method in the psychomotor and affective domains.

\section{E. REFERENCES}

Alrayah, H. (2018). The Effectiveness of Cooperative Learning Activities in Enhancing EFL Learners' Fluency. English Language Teaching, 11(4), 21. https://doi.org/10.5539/elt.v11n4p2 1

Ari, D., \& Sadi, Ö. (2019). Effectiveness of Cooperative Learning on Students' Achievement in Genetics, Self-Efficacy, and Conceptions of Learning Biology. I.E.: Inquiry in Education, 11(2), 4.
Darmawan, I. P. A., \& Sujoko, E. (2013). Revisi Taksonomi Pembelajaran Benyamin S. Bloom. Satya Widya, 29(1), 30. https://doi.org/10.24246/j.sw.2013. v29.i1.p30-39

Fink, L. D. (2003). Creating significant learning experiences for EAL learners. Jossey-Bass Higher and Adult Education Series, 317.

Hafid, H. A. (2011). Sumber dan Media Pembelajaran. Jurnal Sulesana, $6(2), \quad 69-78 . \quad$ journal.uinalauddin.ac.id

Hamdani, A. S. (2009). Taksonomi Bloom dan SOLO untuk Menentukan Kualitas Respon Siswa terahadap Masalah Matematika.

Harsanto, R. (2007). Pengelolaan kelas yang dinamis: Paradigma baru pembelajaran menuju kompetensi siswa. Kanisius.

Huda, M. (2014). Model-Model Pengajaran dan Pembelajaran. pustaka pelajar.

Koç, R. A. Y., Okumuş, R. A. S., \& Öztürk, B. (2013). Effect of Cooperative Learning Model on Science and Technology Laboratory Practices Lesson. International Journal on New Trends in Education and Their Implications, October, 42-57.

Lie, A. (2007). Koorperatif Learning (Memperaktikkan Coorperative Learning Di Ruang-Ruang Kelas. Grasindo.

Sardiman. (2012). Interaksi Dan Motivasi Mengajar. Rajawali Press.

Tiger, T. H. (1994). Time Management: Test of a Process Model. Journal of Applied Psychology, 79(3), 381391. https://doi.org/10.1037/00219010.79.3.381 